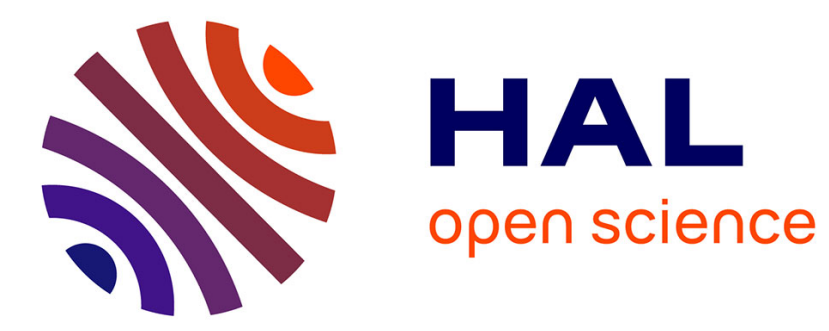

\title{
Patterns in intraspecific variation in root traits are species-specific along an elevation gradient
}

Monique Weemstra, Gregoire T. Freschet, Alexia Stokes, Catherine Roumet

\section{To cite this version:}

Monique Weemstra, Gregoire T. Freschet, Alexia Stokes, Catherine Roumet. Patterns in intraspecific variation in root traits are species-specific along an elevation gradient. Functional Ecology, 2021, Functional Ecology, 35 (2), pp.342-356. 10.1111/1365-2435.13723 . hal-03030429

\section{HAL Id: hal-03030429 \\ https://hal.science/hal-03030429}

Submitted on 30 Nov 2020

HAL is a multi-disciplinary open access archive for the deposit and dissemination of scientific research documents, whether they are published or not. The documents may come from teaching and research institutions in France or abroad, or from public or private research centers.
L'archive ouverte pluridisciplinaire HAL, est destinée au dépôt et à la diffusion de documents scientifiques de niveau recherche, publiés ou non, émanant des établissements d'enseignement et de recherche français ou étrangers, des laboratoires publics ou privés. 


\section{Functional Ecology}

\section{Patterns in intraspecific variation in root traits are species-specific along an elevation gradient}

Monique Weemstra ${ }^{1,2^{*}}$, Grégoire T. Freschet ${ }^{1,3}$, Alexia Stokes ${ }^{2}$, Catherine Roumet ${ }^{1}$

${ }^{1}$ CEFE, Univ Montpellier, CNRS, EPHE, IRD, Univ Paul Valéry Montpellier 3, Montpellier, France; ${ }^{2}$ AMAP, INRAE, CIRAD, IRD, CNRS, University of Montpellier, Montpellier, France; ${ }^{3}$ Station d'Ecologie Théorique et Expérimentale, UMR 5321 (CNRS - Université Toulouse III), 2 route du CNRS, 09200 Moulis, France

* Correspondence author. Email: moniqueweemstra@hotmail.com

\section{Acknowledgements}

We thank our very helpful students and colleagues for their great contribution in the field and in the lab: Guillermo Ángeles, Fabien Anthelme, Manon Bounous, Aristide Chauveau, Yamei Chen, Nereyda CruzMaldonado, Mathieu Fontaine, Stephane Fourtier, Daniel Hernández Cáceres, Leonor Jiménez, Leo Le Fèvre, Beatriz Marín-Castro, Zhun Mao, Luis Merino-Martín, Awaz Mohamed, Hans Reijnen and Hervé Rey. We thank Christian Piedallu for modelling and supplying the climate data for our study site. We also acknowledge the useful comments of two anonymous reviewers, and the thorough review of our manuscript by the Associate Editor, Dr E. J. Sayer, that helped improve this manuscript. Funding was provided by the French and Mexican governments (ECOPICS project, ANR-16-CE03-0009 and CONACYT-2 73659). Thanks are due to the Mairie de Chamrousse for access to field sites.

\section{Authors' contribution}

MW, GTF and CR conceived the ideas and designed methodology; MW, GTF, AS and CR collected the data; MW analysed the data and led the writing of the manuscript, with help from GTF, CR and AS. All authors contributed critically to the drafts and gave final approval for publication.

\section{Data accessibility}

All relevant data are accessible via the INRAE Repository (https://doi.org/10.15454/J1QDPM; Weemstra et al. 2020) and will be made available in the fine-root ecology database (FRED).

This article has been accepted for publication and undergone full peer review but has not been through the copyediting, typesetting, pagination and proofreading process, which may lead to differences between this version and the Version of Record. Please cite this article as doi: $\underline{10.1111 / 1365-2435.13723}$

This article is protected by copyright. All rights reserved 
DR MONIQUE WEEMSTRA (Orcid ID : 0000-0002-6994-2501)

Article type : Research Article

Section: Plant Physiological Ecology

Editor: Dr Emma Sayer

Patterns in intraspecific variation in root traits are species-specific along an elevation gradient

\section{Abstract}

1. Intraspecific trait variation is an important driver of plant performance in different environments. Although roots acquire essential resources that vary with the environment, most studies have focused on intraspecific variation in leaf traits, and research on roots is often restricted to a few species. It remains largely unclear how and to what extent root traits vary with the environment and whether general intraspecific patterns exist across species.

2. We compared intraspecific variation in specific root length (SRL), root diameter, root tissue density (RTD) and root branching density of 11 species along a $1000 \mathrm{~m}$ elevation gradient in the French Alps. We tested 1) the extent of intra- versus interspecific root trait variation along the gradient, 2) whether intraspecific trait patterns with elevation were consistent among species and 3) whether environmental variables better explained intraspecific variation in root traits than elevation. Specifically, we hypothesised that within a species, root trait values would adjust to enhance resource acquisition (either through an increase in SRL or root diameter, and/or branching density) and/or conservation (increased RTD) at higher elevations.

3. Species identity explained most of the overall variation in root traits. Elevation explained only a minor proportion of intraspecific root trait variation, which varied more strongly within than between elevations. Also, trait relationships with elevation rarely agreed with our hypotheses, 
varied strongly across species, and were often differently related to environmental variation. Generally, climate, soil and vegetation properties better explained intraspecific root variation than elevation, but these relationships were highly species-dependent.

4. Along complex environmental gradients where multiple properties simultaneously change, roots of different species vary in different ways, leading to species-specific patterns in intraspecific root trait variation. The lack of support for our hypotheses may be caused by the multiple interactions between environmental properties, small-scale soil heterogeneity, species phylogeny, and changing plant-plant interactions. Our findings suggest that, to enhance our understanding of the effects of environmental change on plant performance, we need to better integrate the multiple dimensions of plant responses to change and measure a broader set of root traits and environmental variables.

\section{Key words}

alpine and montane systems; elevation gradient; intraspecific root trait variation; root branching; root diameter; root tissue density; specific root length; trait-environment relationships

\section{Introduction}

A range of theoretical ecological frameworks has been built on the premise that intraspecific trait variation is negligible, so that species' rankings based on their mean trait values remain robust across environments (Garnier et al., 2001; Westoby, Falster, Moles, Vesk, \& Wright, 2002). Recent studies show however, that intraspecific trait variation can be substantial compared to interspecific trait variation (Niu et al., 2020; Siefert et al., 2015), and can have important consequences for plant performance, interactions among plants, between plants and their environment, community dynamics, and mitigating climate effects on plants (Albert et al., 2011; Anderson \& Gezon, 2015; Read et al., 2017; Siefert et al., 2015; Violle et al., 2012). Therefore, determining the degree of, and patterns in, intraspecific trait variation is extremely important for understanding key physiological and ecological plant processes in different environments. However, most studies have focused on intraspecific variation in leaf traits (e.g., Albert et al., 2010; Anderson \& Gezon, 2015; Kichenin et al., 2013; Messier et al., 2010; Read et al., 2017), whereas intraspecific trait variation of roots may be of equal importance, since plant performance depends on the uptake of water and nutrients that can be regulated through changes in root functional trait expression. Studies investigating intraspecific root trait variation are usually restricted to a single (e.g., Bristiel et al., 2019; Defrenne et al., 2019; Ostonen et al., 2007; Ostonen et al., 2011; Zadworny et al., 2016) or small number of species (Freschet et al., 2018; Kumordzi et al., 2019; Read et al., 2017) and general patterns

This article is protected by copyright. All rights reserved 
remain largely unclear (Bardgett et al., 2014). Here, we test how roots of 11 species change with environmental variation, by examining how root traits vary along an elevation gradient.

Elevation gradients are considered valuable systems to examine plant responses to environmental change (Sundqvist et al., 2013). With elevation, a multitude of climate and soil variables that impact plant performance change within a relatively small distance. In temperate regions, higher elevations are colder and wetter than lower ones, have shorter growing seasons and marked seasonality, and are characterised by a distinct vegetation adapted to the extreme variations in climate that can be experienced (Körner, 1999; Sundqvist et al., 2013). High-elevation soils are usually more heterogeneous in terms of soil nutrient availability (Holtmeier \& Broll, 2005), and less fertile than soils at lower altitudes (Sveinbjornsson et al., 1995), as cooler temperatures slow down microbial activity (Loomis et al., 2006; Mayor et al., 2017), mineralization rates (Sveinbjornsson et al., 1995) and the decomposition of both leaf and root litter (Loomis et al., 2006; Moore, 1986; See et al., 2019).

The climate and soil properties that are modified along elevation gradients can strongly affect intraspecific root trait variation. For example, plants growing in colder and/or low-resource environments - such as high-elevation sites - often have root traits favouring resource foraging, such as small diameter and high specific root length (SRL, root length per unit root dry mass), or thick roots reflecting higher mycorrhizal colonization rates (Chen et al., 2016; Kong et al., 2014; Ma et al., 2018) that favour uptake through greater hyphal length (McCormack \& Iversen, 2019). These two contrasting strategies reflect the 'fungal collaboration axis' recently identified across species, that separates thick-rooted species that depend on mycorrhizal fungi from species with high SRL that rely more on their roots to acquire soil resources (Bergmann et al., 2020); these two alternative strategies may also exist within species along environmental gradients, where SRL (Defrenne et al., 2019; Hill et al., 2006; Zhou et al., 2019) or mycorrhizal colonization rates (Ostonen et al., 2011; Read et al., 2004; Zadworny et al., 2016) are significantly greater for plants on colder, less fertile or drier sites than for conspecific plants in more favourable environments. On the nutrient-poor, heterogeneous soils usually found at high elevations, root branching density (i.e., the number of first-order roots, or root tips) can also increase to rapidly exploit resources when roots encounter nutrient-rich patches (Chen et al., 2016; Zadworny et al., 2016). Finally, plants at high elevations can possess root traits that reduce the loss of scarce resources, such as high root tissue density (root dry mass per unit fresh root volume), that generally contributes to root longevity, minimising resource loss and extending the period during which roots acquire nutrients (Eissenstat, 2000; Ryser, 1996).

Specific root length, root tissue density and root diameter are not fully independent from each other. Mathematically, root diameter and tissue density negatively affect SRL (Ostonen, Püttsepp, et al., 2007). Nevertheless, empirical studies show that different species can produce roots with a variety of 
combinations of SRL, root diameter and tissue density values, demonstrating that a range of root trait strategies can co-exist for plants to adjust uptake strategies (Bergmann et al., 2020; Kramer-Walter et al., 2016; McCormack \& Iversen, 2019). It is also likely that within species, plants can simultaneously adopt acquisitive root trait strategies (i.e., by increasing SRL or root diameter and associated mycorrhizal colonization, and increasing branching density) and conservative strategies (i.e., by increasing root tissue density and prolonging root lifespan), to control resource uptake or conservation in resource-poor, cold environments.

Variation in root traits along complex environmental variations along elevation gradients can occur concurrently or be decoupled in space (different influences predominantly occurring at different elevations). For example, as cold versus dry conditions are generally found at the two opposite ends of a temperate elevation gradient, plants may have a higher SRL at low, drier elevations, and at high elevations with lower temperatures and nutrient availability, leading to U-shaped patterns in SRL along an elevation gradient. Such nonlinear patterns along elevation gradients have been observed for root turnover rates (Graefe et al., 2008), nutrient concentrations (He et al., 2016) and arbuscular mycorrhizal colonisation (Kotilínek et al., 2017). As a consequence, to understand the mechanisms that drive intraspecific patterns in root trait variation, multiple environmental properties that vary along the same gradient need to be taken into account and these could have more direct and stronger impacts on root trait variation than elevation itself, as has been suggested for leaf traits (Midolo et al., 2019).

The type and strength of intraspecific root trait adjustments to elevation probably depends partially on species identity, as shown for leaves along elevation gradients (Albert et al., 2010; Kichenin et al., 2013) and roots along climatic and rainfall gradients (Kumordzi et al., 2019; Zhou et al., 2019). These idiosyncrasies may result from species' differences in environmental preferences that can cause their leaves and roots to vary differently to environmental factors along the gradient (Albert et al., 2010; Kichenin et al., 2013). Root trait patterns along elevation or environmental gradients may also differ between growth forms. Although some studies found no differences between woody and non-woody species in root and leaf intraspecific trait variation along environmental gradients (Kumordzi et al., 2019; Siefert et al., 2015), others observed that herbaceous species displayed greater intraspecific leaf (Midolo et al., 2019) and root trait variation (Zhao et al., 2016) compared to woody species.

This study aims to improve our understanding of intraspecific root trait variation. We investigated whether general patterns in intraspecific root trait variation existed along a $1000 \mathrm{~m}$ elevation gradient in the French Alps, along which environmental variables vary (Supplementary Fig. S1). To this end, we measured SRL, root diameter, root tissue density and branching density on the absorptive roots of 11 locally common herbaceous and woody species. We address three research questions: 1) how much does intraspecific trait variation contribute to overall (i.e., within and across species) root trait variation along 
the gradient? 2) Are patterns in intraspecific root trait variation along an elevation gradient consistent across species? 3) Do climate, soil and vegetation variables better explain intraspecific variation in root traits than elevation? Question 1 focuses on the extent of intraspecific variation, and we expected (Hypothesis 1) that intraspecific root trait variation is considerable given the environmental variation along the elevation gradient, but still lower than interspecific root trait variation. Question 2 focuses on the type of trait patterns along the elevation gradient, and we expected (Hypothesis 2) that species show different relationships between root traits and elevation, because there are different ways to acquire and conserve resources belowground. More precisely, we hypothesise that with increasing elevation and associated environmental change, a) either SRL or root diameter will increase to more efficiently acquire nutrients via roots or mycorrhizas, respectively, and/or b) root branching density will increase to exploit heterogeneously distributed soil resources, and/or c) root tissue density will increase to enhance resource conservation. Regarding our third question, we hypothesised (Hypothesis 3) that root trait relationships with environmental variables are stronger than with elevation, because the local environment is more directly linked to root functioning.

\section{Materials and methods}

\section{Study site characterisation and sampling}

Our study site was an elevation gradient between 1400 and $2400 \mathrm{~m}$ a.s.l. on a southwest-facing slope, located in the Belledonne Massif in the French Alps (N 45 7' 1", E 5 53' 35") (Supplementary Fig. S1). Bedrock along the gradient was composed of variscan metamorphic rocks and ophiolitic complexes (Guillot et al., 1992; Ménot, 1988). Climatic data (mean annual temperature (MAT) and mean annual precipitation, including snow (MAP)) were obtained from the Digitalis database (Laboratoire SILVA, Université de Lorraine-AgroParisTech-INRAE). Mean annual temperature and MAP were modelled and mapped at $1 \mathrm{~km}^{2}$ resolution using GIS (Ninyerola et al., 2000) based on spatially distributed variables that characterise the geography, topography (altitude, slope, exposure, distance to the sea) and land-use (Bertrand et al., 2011; Piedallu et al., 2019; Piedallu et al., 2013; AMAP, 2020; https://data.inrae.fr/dataverse/ecopics). From 1400 to $2400 \mathrm{~m}$ a.s.1. MAT decreased from $8.5^{\circ} \mathrm{C}$ to $5.7^{\circ} \mathrm{C}$, MAP increased from $1024 \mathrm{~mm}$ to $1187 \mathrm{~mm}$, and the length of the growing season (i.e., number of months where the mean monthly temperature exceeded $5^{\circ} \mathrm{C}$; Jones \& Briffa, 1995) decreased from 7.7 to 6.5 months and was highly correlated with MAT (Pearson $\mathrm{r}=1, \mathrm{P}<0.001, \mathrm{~N}=11$ ). Sites at $2400 \mathrm{~m}$ a.s.l. were slightly warmer and received less rainfall than the sites at 2200 and $2300 \mathrm{~m}$ a.s.l. (Supplementary Fig. S1; Table S1); this is counterintuitive and may be caused by the resolution of the climate models used, but these differences were small. The treeline lies between 2000 and $2100 \mathrm{~m}$ a.s.l. and is defined by

This article is protected by copyright. All rights reserved 
the replacement of acidophilous Picea abies forests (Vaccinio myrtilli-Piceetea abietis) by arctico-alpine heath (Loiseleurio procumbentis-Vaccinietea microphylli) (Bardat et al., 2004).

Our study was conducted in five $20 \times 20 \mathrm{~m}$ replicate plots per altitude that were established every $100 \mathrm{~m}$ increase in elevation along the gradient. These plots were similar in slope $\left(17.5 \pm 5.6^{\circ}\right)$ and aspect (south-west) and were located at an average distance of $100 \mathrm{~m}$ from each other below the treeline and 50 $\mathrm{m}$ between plots above the treeline; the average distance between replicate plots ranged between $300 \mathrm{~m}$ and 2000 m (AMAP, 2020; https://data.inrae.fr/dataverse/ecopics). A botanical survey was performed on each plot and vascular plants were identified at the species level following the Flora Helvetica (Lauber et al., 2018). The ground cover of trees, shrubs, herbs, bryophytes, rocks and bare soil was estimated, and vegetation ground cover (i.e., the percentage of ground surface covered by vegetation versus bare soils) significantly decreased with increasing elevation (Supplementary Fig. S1; Table S1; AMAP, 2020; https://data.inrae.fr/dataverse/ecopics). In June and July 2018, we sampled mature plants from 11 vascular species (Table 1). We aimed to sample one plant per species in each of the five replicate plots, leading to five individuals per species per altitude. However, not all species were present at all elevations, and we only found three or four individuals of some species per elevation (Table 1) resulting in a total of 434 plants measured. Species were selected to comprise different growth forms (grasses, forbs, shrubs, and trees) and to occur across a range of consecutive elevations; the number of species per elevation ranged from five to 11 (Table 1).

Ten soil samples were collected from the top $10 \mathrm{~cm}$ soil below the litter layer in each plot. Samples were pooled per elevation, air-dried, sieved to $2 \mathrm{~mm}$ and their soil texture (sand, loam and clay content), total soil organic carbon $(\mathrm{C})$, nitrogen $(\mathrm{N})$ and phosphorus $(\mathrm{P})$ content, soil $\mathrm{pH}$ and cation exchange capacity (CEC) determined (Supplementary Table S1). Soil texture was measured using the Robison's pipette and sieving techniques (Pansu \& Gautheyrou, 2006). CEC ( $\mathrm{cmol} \mathrm{kg}^{-1}$ ) was determined in a cobalihexamin solution using the Matson method (Ciesielski et al., 1997) and pH was measured in water. Total soil organic $\mathrm{C}$ and $\mathrm{N}$ contents were determined by dry combustion (Girardin \& Mariotti, 1991), soil P content was estimated with the Olsen method (Olsen et al., 1954). A different soil sampling experiment revealed that soil bulk density significantly increased with altitude (Supplementary Table S1; Pearson $\mathrm{r}=0.50, \mathrm{P}<0.001, \mathrm{~N}=70$ ); these data were collected in the same plots but at fewer elevations (between 1400 and $2400 \mathrm{~m}$ a.s.l. every $200 \mathrm{~m}$ increase in altitude) and from soil samples collected under Juniperus communis, Picea abies, and Vaccinium myrtillus (AMAP, 2020; https://data.inrae.fr/dataverse/ecopics).

\section{Root trait measurements}

This article is protected by copyright. All rights reserved 
Roots from 11 species were carefully dug out from the top $15 \mathrm{~cm}$ soil horizon and below the litter layer. For woody species (shrubs and trees), 3 - 5 different root branches were dug up from approximately 0.5 $1.5 \mathrm{~m}$ from the base of the stem, and traced back to the stem to verify that they belonged to the chosen individuals. For herbaceous species (grasses and forbs), we dug out virtually entire root systems. For woody and herbaceous species, whose roots were growing too deep or too wide to collect all roots, we ensured we had retrieved sufficient absorptive roots to perform reliable root trait measurements (see below). Roots with adhering soil were stored in moist plastic bags and kept refrigerated until further processing and analyses in the laboratory. Within one day but sometimes up to two days after sampling, roots were washed, and non-damaged absorptive roots selected for further analyses; for herbaceous plants with large root systems, we selected a subsample of absorptive roots that was morphologically representative of the entire root system. We defined absorptive roots as the first- and second-order roots following the morphometric classification (first-order roots are the most distal orders), except for grasses whose third-order roots were considered absorptive if they were densely covered by root hairs. Roots were scanned in water using a flatbed scanner with a backlight system (Epson Perfection V800 Photo) at $800 \mathrm{dpi}$; for herbaceous species, roots were stained with methyl-violet $\left(5 \mathrm{~g} \mathrm{~L}^{-1}\right)$ to improve contrast. Afterwards, they were oven-dried $\left(60^{\circ} \mathrm{C}, 48 \mathrm{~h}\right)$ and their dry mass determined.

Root scans were analysed with WinRhizo pro (version: 2009c; Regent Instruments, Canada) to obtain data on the root length and root volume in different diameter classes (from $0-2 \mathrm{~mm}$ diameter with a $0.1 \mathrm{~mm}$ bin size). From these data, we determined SRL (total root length / total root dry mass), mean root diameter, and root tissue density (root dry mass / total root fresh volume in diameter classes) (Freschet et al., 2020; Rose, 2017). We used root diameter as a proxy for mycorrhizal colonization rates as we did not measure this. We measured root branching density (i.e., number of first-order roots per length second-order roots) from these same root scans based on up to five representative second-order root segments per scan (ImageJ, http://rsbweb.nih.gov/ij/). The root branching density was averaged across all measurements per individual plant, and the mean branching density per plant was treated like the other root traits in our statistical analyses.

\section{Statistical analyses}

We first tested intraspecific relationships between SRL, root diameter and tissue density, as these are not fully independent. Within each species and for each trait pair, we applied a linear, a second-degree polynomial and an exponential model to select the best model based on their Akaike information criterion (AIC), and then tested these relationships for the best model.

To address the first research question and corresponding hypothesis, we quantified the extent of intra- and interspecific root trait variation by calculating the coefficient of variation of SRL $\left(\mathrm{CV}_{\mathrm{SRL}}\right)$, 
diameter $\left(\mathrm{CV}_{\text {dia }}\right)$, root tissue density $\left(\mathrm{CV}_{\mathrm{RTD}}\right)$ and branching density $\left(\mathrm{CV}_{\mathrm{BD}}\right)$ (trait standard deviation / trait mean $* 100 \%$ ) within each species and across all species combined. In addition, we partitioned the root trait variance between biologically hierarchical (nested) levels across all individual plants (i.e., at the replicate plot level) to determine to what extent growth form, species, elevation, and replicate plot explain overall root trait variation. More specifically, we determined the percentage of trait variance explained by differences between growth forms; between species; within species between elevations (i.e., intraspecific trait variation along the elevation gradient); and within species within elevations (i.e., intraspecific trait variation at the same elevation). We applied a linear mixed model to partition the variance in root traits with a given trait as the dependent factor and only random effects ('elevation' (i.e., conspecific plants between elevations) nested in 'species' nested in 'growth form'). The remaining variance was explained by trait differences between conspecific plants growing in different replicate plots at the same elevation (Albert et al., 2010).

The relationship between root traits and elevation (research question 2) or environmental properties (research question 3) and our trait-specific hypotheses (Hypothesis 2) were tested with a linear regression model with the trait as dependent, and elevation or a single environmental property as independent variables. We were unable to test multiple regression models as we lacked the information to specify which environmental variables would be linearly or nonlinearly related to root traits. We applied linear or second-degree polynomial models for each trait and each species depending on their AIC. The environmental variables tested included MAT, MAP, CEC, soil $\mathrm{N}$ content, $\mathrm{pH}$, sand content and vegetation ground cover, that all reflect different and largely independent elements of the plant's environment (e.g., temperature, water and nutrient supply, and competition). We used the AIC values of these models to determine whether environmental properties or elevation best explained intraspecific root trait variation (Hypothesis 3 ) and considered models equally good if the difference in their AIC ( $\triangle$ AIC) was less than two.

We also compared root trait relationships with elevation or environmental variables between growth forms and between all plants using mixed models. Elevation or a single environmental variable was included as a fixed factor; for the models per growth form, 'species' was a random factor, and for the models across all plants, 'species' nested in 'growth form' were random factors. All statistical tests were carried out in the R statistical software (R Core Team, 2019) using the lme4 (Bates et al., 2015) and MuMIn (Barton, 2019).

\section{Results}

When all species were pooled together, SRL and root diameter, and SRL and root tissue density were significantly correlated with each other, following a negative exponential relationship (Fig. S2a,b). The 
relationship between root diameter and root tissue density was significant and best described by a Ushaped relationship (Fig. S2c).

\section{The contribution of intraspecific variation to overall root trait variation (Hypothesis 1)}

The variance in SRL, diameter and branching density across all individuals combined was mostly explained by species identity (20 to 70\%; Fig. 1). Overall (i.e., across all plants) intraspecific trait variation accounted for 20 to $35 \%$ of this variation, but most of it (15-35\% of the total variation) was explained by differences among conspecifics at the same elevation that were sampled at different replicate plots (i.e., ITV $\mathrm{I}_{\text {within }}$ in Fig. 1), and only a small proportion $(1-5 \%)$ by differences between conspecifics along the elevation gradient (i.e., ITV $_{\text {between }}$ in Fig. 1). Growth form explained another $5-15 \%$ of the variance in these traits. The variance in root tissue density was more equally explained by intraspecific trait variation within elevations (37\%), growth form (27\%) and species (24\%), while intraspecific trait variation between elevations explained $12 \%$ of its variance. Trait coefficients of variation (CV) were generally highest for SRL and branching density (on average 35\% and 33\%, respectively), and lowest for root diameter and root tissue density (mean CV 20\%) (Fig. S3). Trait CV was higher at the inter- than at the intraspecific level for SRL, root diameter and root tissue density (except for $V$. myrtillus) but not for branching density.

\section{Intraspecific relationships between root traits and elevation (Hypothesis 2)}

The SRL within eight species was significantly related to elevation (Fig. 2, Supplementary Table S2). Three species had lower SRL and one species had higher SRL with increasing elevation, and four species displayed a U-shaped relationship between SRL and altitude. Elevation explained 14 to $27 \%$ of the intraspecific variation in SRL depending on the species. Between growth forms, SRL significantly decreased with increasing elevation for grasses, showing a U-shaped pattern along the elevation gradient for forbs and shrubs, and did not change significantly with elevation in trees (Supplementary Table S3, Fig. S4). Across all individuals of all species, SRL declined with altitude up to $2000 \mathrm{~m}$ but increased again above $2000 \mathrm{~m}$ a.s.l. (Supplementary Fig. S4). Elevation explained only a minor proportion of the overall variation in SRL $\left(\mathrm{R}_{\mathrm{m}}^{2}=0.01\right.$, Supplementary Table $\left.\mathrm{S} 3\right)$.

Intraspecific variation in root diameter was significantly related to elevation within six species: within one species, diameter increased, in one species it decreased, and in the remaining four species, bell-shaped patterns occurred with increasing elevation (Fig. 2, Supplementary Table S2). Elevation explained 15 to $39 \%$ of the intraspecific variation in root diameter. The grasses, forbs and shrubs displayed a significant bell-shaped relationship between diameter and elevation, whereas in trees, diameter increased with elevation (Supplementary Table S3, Fig. S4). Across all individuals of all

This article is protected by copyright. All rights reserved 
species, root diameter showed a significant, bell-shaped pattern along the elevation gradient, with the thickest roots occurring at $1960 \mathrm{~m}$ a.s.l. (Fig. S4), but only explained a marginal part of overall root trait variation $\left(\mathrm{R}_{\mathrm{m}}^{2}=0.01\right.$; Supplementary Table $\left.\mathrm{S} 3\right)$.

Seven species showed a significant relationship between root tissue density and elevation (Fig. 2, Supplementary Table S2). One species had a bell-shaped pattern, five species had higher, and one species had lower root tissue density with increasing altitude; elevation explained 12 to $29 \%$ of intraspecific trait variation in root tissue density. The root tissue density of grasses and shrubs increased with elevation, whereas forbs and trees did not demonstrate any particular significant patterns (Supplementary Table S3, Fig. S4). Across all individuals of all species, root tissue density significantly increased at higher elevations (Fig. S4), but elevation explained only $2 \%$ of its variation (Supplementary Table S3).

Branching density varied significantly with elevation within four species, and these changes were linear and positive within two species, U-shaped within one species, and bell-shaped within another species (Fig. 2, Supplementary Table S2). Elevation explained $12-19 \%$ of the intraspecific variation in branching density. Regarding the different growth forms, the branching density of grasses increased with elevation, and followed a bell-shaped pattern for shrubs, but did not change significantly for forbs and trees (Supplementary Table S3, Fig. S4). Across all individuals, branching density significantly increased at higher elevations (Fig. S4), but only $1 \%$ of the variation was explained by elevation (Supplementary Table S3).

Root trait relationships with environmental variables versus relationships with elevation (Hypothesis 3)

Shapes and strengths of intraspecific relationships between SRL and environmental variables differed largely between species (Fig. 3a, Supplementary Table S4). The most consistent patterns were observed for climate variables: SRL increased with MAT (four species) and decreased with MAP (five species; Fig. 4a). Specific root length was also significantly related to vegetation ground cover within six species, and these relationships were positive, negative or U-shaped (Fig. 3a). Relationships between SRL and soil properties were even more variable: within five species, SRL was significantly related to soil $\mathrm{pH}$ and $\mathrm{N}$ content and these relationships were either negative, U- or bell-shaped. Specific root length varied with sand content within only two species (a negative and a bell-shaped pattern occurred), but not with CEC within any of the species. As hypothesised, for four species (N. stricta, G. acaulis, H. alpine, J. communis), single environmental models (MAT, MAP, and soil $\mathrm{pH}$, depending on the species) were a better fit for modelling variation in SRL than the elevation model (i.e. they had a lower AIC; Fig. 3a, Supplementary Table S4). For four species, elevation and environmental models were equally good (i.e., $\triangle \mathrm{AIC}<2$ ), while for three species, intraspecific variation in SRL was not explained by any of the elevation or environmental models.

This article is protected by copyright. All rights reserved 
Intraspecific variation in root diameter was mostly related to MAP (Fig. 4b), but the shape of these relationships depended upon the species, with positive (two species), negative (one species), bellshaped (three species) and U-shaped (one species) relationships (Figs 3b, 4b, Supplementary Table S4). Intraspecific variation in root diameter was related to variation in MAT (five species), sand content (five species) and $\mathrm{N}$ content (four species) but here too, the shapes of these relationships were highly variable between different species (Fig. 3b). Root diameter was positively (three species) and negatively (one species) related to vegetation ground cover and varied with soil $\mathrm{pH}$ and CEC within one species each (root diameter increased with decreasing CEC, and with increasing $\mathrm{pH}$ ). For six species (N. stricta, $H$. alpine, P. ostruthium, J. communis, V. myrtillus, and S. aucuparia), single environmental were better fits to the variation in root diameter than the elevation model (Fig. 3b). For three species, variation in root diameter was best described by both the elevation model and by single environmental models, especially MAT and MAP, and for two species none of the models explained variation in root diameter.

Variation in root tissue density of most species was related to changes in vegetation ground cover (Fig. 4c), MAT and MAP (six, five and four species, respectively), but depending on the species, these relationships were positive, negative, U-shaped, bell-shaped or non-significant (Fig. 3c, Supplementary Table S4). Root tissue density varied with CEC in three species (these relationships were negative and linear, or bell-shaped) and to sand content (positively within two species, bell-shaped relationship within two species). Root tissue density did not change with any of the environmental variables in three species. The best model(s) were environmental models for four species (i.e., C. sempervirens, N. stricta, G. acaulis, H. alpina), but the significant predictors differed between species. For three other species, elevation and environmental models were equally good, and for one species, elevation was the single best predictor of variation in root tissue density. Three species showed no significant relationships between root tissue density and elevation or environmental variables.

Branching density was mostly and consistently related to variation in CEC: four species had less branched roots with higher CEC (Figs 3d, 4d, Supplementary Table S4). Variation in branching density within two to three species was related to changes in the other soil variables and vegetation ground cover: generally, it increased with sand content (two species) and soil $\mathrm{pH}$ (two species), it decreased with vegetation ground cover (two species), and showed a bell-shaped relationship with soil $\mathrm{N}$ content (two species). In addition, branching density was negatively related to MAT (one species), and positively to MAP (two species). For seven species (i.e., A. odoratum, D. flexuosa, H. alpina, P. ostruthium, J. communis, V. myrtillus, S. aucuparia), the best models included only single environmental properties that mostly represented soil properties, but predictors varied between species (Fig. 3d). For one species, elevation and CEC were equally good, and for two species, neither elevation nor environmental variables explained variation in branching density.

This article is protected by copyright. All rights reserved 
Finally, when all individuals of all species were considered together in one model, we observed significant relationships between root traits and elevation and environmental variables. However, these variables explained only a marginal proportion of the trait variation (mostly less than 2\%); the contribution of the random factors ('species' nested in 'growth form') was substantial but does not account for intraspecific trait variation (Supplementary Tables S3, S5). SRL was significantly and negatively related to MAP (Figs 3a, 4a) and soil $\mathrm{pH}$, and root diameter was positively related to soil $\mathrm{pH}$ (Fig. 3b). Root tissue density decreased significantly with increasing MAT, CEC, and vegetation ground cover (Figs 3c, 4c), and with decreasing MAP and soil $\mathrm{N}$ content. Branching density was positively related to MAP, sand content and soil pH, and negatively to CEC (Figs 3d, 4d).

\section{Discussion}

\section{Low intraspecific variation in root traits with elevation}

Although there was considerable intraspecific variation in root traits across our 11 study species, this was largely owing to trait differences between conspecifics within a given altitude (i.e., between replicate plots at the same altitude) rather than along the 1000 m elevation gradient. Defrenne et al. (2019) also found that their smallest sampling scales - i.e., the individual root branch and the soil blocks from which roots were collected - explained up to $100 \%$ of root trait variation of Douglas fir trees along a 600-km, biogeographic gradient in Canada. Similarly, Kumordzi et al. (2019) showed that a large part of root trait variation was explained at the local (i.e., sites within their gradient with comparable climate and soil characteristics) rather than at the regional scale (i.e., their $\sim 5000 \mathrm{~km}$ long gradient). The large heterogeneity of soils at small spatial scales (Ettema \& Wardle, 2002) may cause roots to respond to very local soil properties, for example by producing more lateral roots when encountering a nutrient-rich patch (Hodge, 2004). Especially in competition with other plants, this ability to show strong root responses to small-scale environmental changes may have considerable benefits to plant performance on infertile, patchy soils (Hodge, 2004; Hutchings et al., 2003). These results emphasise the necessity to better characterise the microenvironment of the roots sampled, for example by measuring soil resource availability and bulk density, the density and identity of neighbouring plants, and microbial properties, such as mycorrhizal or decomposer community composition, that are all known to influence intraspecific root trait variation (Defrenne et al., 2019; Ettema \& Wardle, 2002; Hutchings et al., 2003). The large intraspecific root trait differences within a given elevation further imply that interpreting mean values of trait data at the species level requires careful consideration of the environmental context at small ecological scales.

This article is protected by copyright. All rights reserved 
In line with our first hypothesis, species' identity was the best predictor of root trait variation; it explained $20-70 \%$ of the total variation in root traits, and the CV of SRL, root diameter and root tissue density was generally higher at the inter- than the intraspecific level. Read et al. (2017) found the opposite pattern for SRL, but other studies found outcomes similar to ours (Burton et al., 2017; Ding et al., 2020; Valverde-Barrantes et al., 2013). Root trait variation at the community level may thus be generally more strongly driven by species' turnover than intraspecific root trait variation, but as species in our study did not make up the majority of the vegetation cover at all elevations, we could not test this potential consequence. Although climate and soil properties changed substantially along the gradient, elevation explained only a minor proportion $(1-5 \%)$ of overall root trait variation compared to other studies that covered larger environmental gradients. For instance, the gradients considered by Zadworny et al. (2016) and Ostonen et al. (2011) covered considerably larger variation in MAT (6-fold and 8-fold variation in MAT, respectively; and 2.5 fold variation in MAP in Ostonen et al. (2011) than found along our gradient (i.e., 2.2-fold variation in MAT, 1.2-fold variation in MAP). At the same time, elevation explained between $10 \%$ and $40 \%$ of the intraspecific root trait variation, because the individual species' regression models (Fig. 2) allowed the testing of non-linear models, whereas our variance partitioning analyses across all plants of all species together (Fig. 1) assumed linear relationships only. Depending on the species and trait of interest, non-linear variation in trait relationships with complex environmental gradients needs to be considered to determine how (much) individual species respond to environmental change.

\section{Idiosyncratic root trait patterns along a complex environmental gradient}

As expected (Hypothesis 2), we found virtually no general patterns in intraspecific root trait variation with elevation across 11 species: we observed linear (positive and negative), nonlinear (bell- and Ushaped) or no relationship between root traits and altitude. We further hypothesised that trait values would increase with elevation as this would contribute to resource acquisition (for SRL, root diameter and branching density) or conservation (for root tissue density), but SRL and root diameter increased for only one species, root branching density increased within two species, and root tissue density increased within five species. These different trait patterns could not be attributed to different growth forms, as has been observed elsewhere on root (Zhao et al., 2016) and leaf traits (Midolo et al., 2019), because in our study, root trait patterns were highly variable within growth forms, and overlapping between species of different growth forms (Supplementary Fig. S4). Prior studies also observed idiosyncratic patterns in leaf (Albert et al., 2010; Kichenin et al., 2013; Read et al., 2017) and root trait variation along various environmental gradients (Kumordzi et al., 2019; Roybal \& Butterfield, 2019; Zhou et al., 2019) suggesting that idiosyncrasy in intraspecific trait patterns may be a widespread phenomenon. As the different degrees of,

This article is protected by copyright. All rights reserved 
and patterns in intraspecific trait variation may be influenced by species' phylogenetic background (Kembel \& Cahill., 2005), phylogeny may be relevant to account for in future work.

The complexity of our elevation gradient may at least partly explain why patterns in trait variation are species-specific. Plants are expected to have an optimised array of traits to enhance the uptake of the most limiting resource (Hill et al., 2006; Ryser \& Eek, 2000) and often have adaptive responses to cope with environmental stresses (Sultan, 2000). Along elevation - and other natural gradients, the most limiting factor(s) and the dominant stress can vary (Sundqvist et al., 2013) and such conditions may be perceived differently by co-occurring species (Valladares et al., 2007), leading to divergent trait responses among species (e.g., Freschet et al., 2018; Kichenin et al., 2013). For example, for trees, temperature is a stronger limitation for plant functioning than for herbaceous species, as reflected by the existence of treelines at high altitudes across the world (Hoch \& Körner, 2012; Körner, 1998), whereas light may be strongly limiting for herbaceous species in forested areas below the treeline, but less so for trees. Although we could not test multiple regression models (see Methods section), the multivariate nature of our elevation gradient likely plays a role in the non-linear variation of root traits with elevation. The different resource requirements of species, the shifts in resource limitations along the gradient, and the existence of alternative ways to respond to these shifts can therefore in part explain idiosyncratic (linear versus nonlinear) root relationships along the elevation gradient.

\section{Intraspecific root trait relationships with elevation and environmental variables}

In line with our third hypothesis, changes in environmental variables along our elevation gradient better explained intraspecific root trait variation. However, the shapes and strengths of the root trait relationships with these environmental properties were also highly variable: a given root trait varies in different ways with different environmental properties depending on the species. Here we discuss which and how climate, soil or vegetation properties were related to intraspecific variation per root trait.

Mean annual precipitation was the most important variable to explain intraspecific variation in SRL for five of our 11 study species, but how it relates to SRL remains difficult to interpret. Within these five species, SRL was higher at sites that received less precipitation (i.e., lower elevations) where it may contribute to water uptake; however, several studies have reported no intraspecific changes in SRL along drought or rainfall gradients (Bristiel et al., 2019; Ostonen, Püttsepp, et al., 2007; Zhou et al., 2019) and drought may not be an important factor for plants at these lower elevation sites at the Belledonne Massif given the ample rainfall (Supplementary Table S1). Four of these five species also had higher SRL on warmer sites (i.e., lower elevations), so that to some extent, changes in SRL with MAP may reflect a response to MAT. We hypothesised that SRL would increase with elevation because this would enhance resource uptake (Freschet \& Roumet, 2017) on colder sites with slower nutrient cycling and lower 
nutrient availability (Loomis et al., 2006; Mayor et al., 2017; Sveinbjornsson et al., 1995) (Hypothesis 2a). However, SRL was lower at colder sites, warmer sites did not have higher soil $\mathrm{N}$ or P contents, and SRL rarely varied with the soil fertility indicators that we measured such as CEC or soil N. The links between SRL, climate and soil properties are thus unclear. We could not separate direct effects of temperature and the length of the growing season (which were highly correlated) from indirect effects via soil nutrient availability, but the inconsistent root trait relationships with soil fertility variables may suggest a stronger and direct relationship between intraspecific root trait variation and temperature along our gradient.

Most species (seven out of 11) showed a significant change in root diameter with MAP, but these relationships were positive, negative, bell- and U-shaped depending on the species. These idiosyncratic patterns may result from the multiple costs and benefits associated with modifying root diameter in different environments. Our hypothesis (2a) is based on the premise that thicker roots may sustain higher mycorrhizal colonization rates which benefits resource uptake. However, this relationship is more firmly established for arbuscular mycorrhizal hosts (as thick roots generally have a larger cortex which is directly related to space for arbuscular mycorrhizal fungi (Kong et al., 2014)) than for ectomycorrhizal host species (Ding et al., 2020; Kong et al., 2014; McCormack \& Iversen, 2019). Thick roots also have lower proliferation rates (Eissenstat, 1991) and foraging precision (Chen et al., 2016); such slower proliferation may be particularly disadvantageous at high altitudes, with typically heterogeneous resource distributions (Holtmeier \& Broll, 2005) and short growing seasons that provide limited opportunities to capture sufficient resources, especially in competition with neighbouring plants (Hutchings et al., 2003). As such, an increase in root diameter at high elevations may not be as beneficial for e.g., ectomycorrhizal as arbuscular mycorrhizal plants, and may not outweigh concomitant disadvantages linked to other soil properties that vary with altitude. Instead, plants may modify traits that we did not measure such as root mass density (Hendriks et al., 2015; Weemstra et al., 2017), exudate composition (De Vries et al., 2019) and uptake kinetics (Jackson et al., 1990) to improve resource availability and acquisition in nutrient-poor and/or heterogeneous soils.

Variation in root tissue density was the most consistent adjustment across all species, with five species producing denser roots at high altitudes as hypothesised (Hypothesis 2c), but among the remaining six species, relationships between elevation and root tissue density varied. Of the environmental properties, variation in root tissue density was for most species associated with changes in vegetation ground cover; three species of these produced denser roots on sites with more sparse vegetation cover. This change in root tissue density potentially reflects the direct buffering effects of vegetation on low temperatures, and/or may indicate an indirect relationship between root tissue density and factors typically responsible for low vegetation ground cover, such as moving soils, eroded soils and 
shallow soils. Our hypothesis that root tissue density increases with elevation is based on the general assumption that dense roots are better protected against adverse conditions like unstable soils, which reduces the loss of resources in low-resource environments. However, evidence for the relationship between root tissue density and lifespan within species is virtually non-existent, and still inconclusive across species (Eissenstat \& Yanai, 1997; McCormack et al., 2012; Ryser, 1996); in fact, a recent study demonstrates that at least across woody species, root lifespan is more strongly determined by root diameter than by root tissue density (Kong et al., 2019). Alternatively, roots may become denser at higher altitudes with denser soils, as dense roots have thicker cell walls to retain turgor pressure in compact soils (Bengough et al., 2006), which is corroborated by the positive relationship between root tissue density and soil bulk density (Linear regression, $\mathrm{F}_{1,98}=7.90, \mathrm{P}=0.006$ ) across the five species that significantly increased their root tissue density with elevation. In sum, while root tissue density showed the most consistent relationships with elevation of all traits, there are several potential mechanisms that can explain these patterns.

The expectation that species would increase root branching density at higher elevations (Hypothesis 2b) to improve resource uptake from increasingly patchy soil resources (Hodge, 2004) was observed in only two species; others demonstrated no relationships or U- and bell-shaped patterns along the gradient. Soil properties were overall the best predictors of intraspecific variation in branching density; in general, branching density increased on poor, basic soils (i.e., with low CEC and high $\mathrm{pH}$ ), on cold sites and with sparse vegetation ground cover, which agrees with the expectation that high branching density is beneficial on nutrient-poor soils (Zadworny et al., 2016). These features all typically characterise high-elevation sites, but surprisingly, direct relationships between root branching and elevation were mostly not significant or nonlinear. In prior studies, intraspecific variation in branching density along environmental gradients is not always straightforward either. For example, root branching density has been shown to decrease (Holdaway et al., 2011), but also (marginally) increase with soil P (Defrenne et al., 2019), and the degree of branching in nutrient patches may differ between species, depending on their nutritional needs and the degree of competition with other plants (Hodge, 2004). The fact that environmental variables typically considered to be important drivers of plant intraspecific trait variation explain only a small part of the variation in root branching density suggests that we need to measure other factors, such as soil micro-heterogeneity and plant-plant interactions to explain variation in root branching.

Root trait covariation between SRL, root diameter and tissue density predicted by mathematical functions did not clearly explain the observed intraspecific root trait relationships with elevation or environmental variables. Negative trait interrelationships would imply opposite trait patterns along our elevation gradient which we only observed within one (root tissue density - diameter: J. communis) or

This article is protected by copyright. All rights reserved 
two species (SRL - diameter: D. flexuosa and J. communis; SRL - root tissue density: A. odoratum and H. alpine) (Fig. 2). Possibly, different environmental properties impact component traits (i.e., root tissue density and root diameter) in different ways, with differential influences on their composite trait (i.e., SRL), which could explain why variation in SRL along elevation or environmental gradients in general is rarely coordinated with the variation in its component traits (Freschet et al., in press). Unravelling these mechanisms requires studying roots in greater detail by studying for example root anatomical properties (e.g., cortex and stele thickness), which underlie variations in root diameter, tissue density and SRL (Freschet et al., 2020; Kong et al., 2019) but are under the influence of different environmental variables (Peterson et al., 1993; Zadworny et al., 2016). Our results on intraspecific root trait variation at least partly agree with previous interspecific observations, whereby a multidimensional trait space allows the synonymous expression of a variety of strategies to respond to environmental drivers (Ding et al., 2020; Bergmann et al., 2020; McCormack \& Iversen, 2019) rather than following one resource acquisitive or conservative strategy.

\section{Conclusion}

This study illustrates the extent to which patterns in intraspecific root trait variation can be speciesspecific along a complex environmental gradient. It further suggests that contrasting sets of trait adjustments across species may be equally adaptive in similar environments (e.g., by investing in the acquisition versus conservation of resources or adopting distinct resource acquisition strategies), to overcome specific environmental constraints. It finally highlights that intraspecific root variation may depend more on small-scale heterogeneity than large-scale environmental variation. Overall, our work emphasises that future studies of complex environmental gradients may need to use more integrative approaches to study and understand plant responses - targeting larger sets of relevant traits and environmental descriptors and accounting for non-linear relationships - to improve our mechanistic understanding of how plants adjust to multiple co-occurring variations in environmental properties.

\section{References}

Albert, C. H., Grassein, F., Schurr, F. M., Vieilledent, G., \& Violle, C. (2011). When and how should intraspecific variability be considered in trait-based plant ecology? Perspectives in Plant Ecology, Evolution and Systematics, 13(3), 217-225. https://doi.org/10.1016/j.ppees.2011.04.003

Albert, C. H., Thuiller, W., Yoccoz, N. G., Soudant, A., Boucher, F., Saccone, P., \& Lavorel, S. (2010). Intraspecific functional variability: Extent, structure and sources of variation. Journal of Ecology, 98(3), 604-613. https://doi.org/10.1111/j.1365-2745.2010.01651.x

This article is protected by copyright. All rights reserved 
AMAP (2020). AMAP Ecopics [Data Repository]. https://data.inrae.fr/dataverse/ecopics. Portail Data INRAE.

Anderson, J. T., \& Gezon, Z. J. (2015). Plasticity in functional traits in the context of climate change: A case study of the subalpine forb Boechera stricta (Brassicaceae). Global Change Biology, 21(4), 1689-1703. https://doi.org/10.1111/gcb.12770

Bardat, J., Bioret, F., Botineau, M., Boullet, V., Delpech, R., Géhu, J.-M., \& Haury, J. (2004). Podrome Des Végétations de France. Muséum national d'histoire naturelle.

Bardgett, R. D., Mommer, L., \& De Vries, F. T. (2014). Going underground: Root traits as drivers of ecosystem processes. Trends in Ecology \& Evolution, 29(12), 692-699. https://doi.org/10.1016/j.tree.2014.10.006

Barton, K. (2019). MuMIn: Multi-Model Inference (R package version 1.43.6) [Computer software]. https://CRAN.R-project.org/package=MuMIn

Bates, D., Mächler, M., Bolker, B., \& Walker, S. (2015). Fitting Linear Mixed-Effects Models Using Ime4. Journal of Statistical Software, 67(1). https://doi.org/10.18637/jss.v067.i01

Bengough, A. G., Bransby, M. F., Hans, J., McKenna, S. J., Roberts, T. J., \& Valentine, T. A. (2006). Root responses to soil physical conditions; growth dynamics from field to cell. Journal of Experimental Botany, 57(2), 437-447. https://doi.org/10.1093/jxb/erj003

Bergmann, J., Weigelt, A., van der Plas, F., Laughlin, D. C., Kuyper, T. W., Guerrero-Ramirez, N., Valverde-Barrantes, O. J., Bruelheide, H., Freschet, G. T., Iversen, C. M., Kattge, J., McCormack, M. L., Meier, I. C., Rillig, M. C., Roumet, C., Semchenko, M., Sweeney, C. J., van Ruijven, J., York, L. M., \& Mommer, L. (2020). The fungal collaboration gradient dominates the root economics space in plants. Science Advances, 6(27), eaba3756. https://doi.org/10.1126/sciadv.aba3756

Bertrand, R., Lenoir, J., Piedallu, C., Riofrío-Dillon, G., de Ruffray, P., Vidal, C., Pierrat, J.-C., \& Gégout, J.-C. (2011). Changes in plant community composition lag behind climate warming in lowland forests. Nature, 479(7374), 517-520. https://doi.org/10.1038/nature10548

Bristiel, P., Roumet, C., Violle, C., \& Volaire, F. (2019). Coping with drought: Root trait variability within the perennial grass Dactylis glomerata captures a trade-off between dehydration avoidance and dehydration tolerance. Plant and Soil, 434(1-2), 327-342. https://doi.org/10.1007/s11104018-3854-8

Burton, J. I., Perakis, S. S., McKenzie, S. C., Lawrence, C. E., \& Puettmann, K. J. (2017). Intraspecific variability and reaction norms of forest understorey plant species traits. Functional Ecology, 31(10), 1881-1893. https://doi.org/10.1111/1365-2435.12898

This article is protected by copyright. All rights reserved 
Chen, W., Koide, R. T., Adams, T. S., DeForest, J. L., Cheng, L., \& Eissenstat, D. M. (2016). Root morphology and mycorrhizal symbioses together shape nutrient foraging strategies of temperate trees. Proceedings of the National Academy of Sciences, 113(31), 8741-8746. https://doi.org/10.1073/pnas.1601006113

Ciesielski, H., Sterckeman, T., Santerne, M., \& Willery, J. P. (1997). A comparison between three methods for the determination of cation exchange capacity and exchangeable cations in soils. Agronomie, 17(1), 9-16. https://doi.org/10.1051/agro:19970102

Defrenne, C. E., McCormack, M. L., Roach, W. J., Addo-Danso, S. D., \& Simard, S. W. (2019). Intraspecific Fine-Root Trait-Environment Relationships across Interior Douglas-Fir Forests of Western Canada. Plants, 8(7), 199. https://doi.org/10.3390/plants8070199

Ding, J., Kong, D., Zhang, Z., Cai, Q., Xiao, J., Liu, Q., \& Yin, H. (2020). Climate and soil nutrients differentially drive multidimensional fine root traits in ectomycorrhizal- dominated alpine coniferous forests. Journal of Ecology, 1365-2745.13407. https://doi.org/10.1111/13652745.13407

Eissenstat, D. (2000). Root structure and function in an ecological context: FORUM Commentary. New Phytologist, 148(3), 353-354. https://doi.org/10.1046/j.1469-8137.2000.00781.x

Eissenstat, D. M. (1991). On the relationship between specific root length and the rate of root proliferation: A field study using citrus rootstocks. New Phytologist, 118(1), 63-68. https://doi.org/10.1111/j.1469-8137.1991.tb00565.x

Eissenstat, D.M., \& Yanai, R. D. (1997). The Ecology of Root Lifespan. Advances in Ecological Research, 27, 1-60.

Ettema, C. H., \& Wardle, D. A. (2002). Spatial soil ecology. Trends in Ecology \& Evolution, 17(4), 177183. https://doi.org/10.1016/S0169-5347(02)02496-5

Freschet, G. T., Pagès, L., Iversen, C. M., Comas, L. H., Rewald, B., Roumet, C., Klimešová, J., Zadworny, M., Poorter, H., Postma, J. A., Adams, T. S., Bagniewska-Zadworna, A., Blancaflor, E. B., Brunner, I., Cornelissen, J.H.C., Garnier, E., Gessler, A., Hobbie, S. E., Lambers, H., ... McCormack, M. L. (2020). A starting guide to root ecology: Strengthening ecological concepts and standardizing root classification, sampling, processing and trait measurements.

Freschet, G. T., \& Roumet, C. (2017). Sampling roots to capture plant and soil functions. Functional Ecology, 31(8), 1506-1518. https://doi.org/10.1111/1365-2435.12883

Freschet, G. T., Roumet, C., Comas, L. H., Weemstra, M., Bengough, A. G., Rewald, B., Bardgett, R. D., De Deyn, G., Johnson, D., Klimešová, J., Lukac, M., McCormack, M. L., Meier, I. C., Pagès, L., Poorter, H., Prieto, I., Wurzburger, N., Zadworny, M., Bagniewska-Zadworna, A., ... Stokes, A.

This article is protected by copyright. All rights reserved 
(in press). Root traits as drivers of plant and ecosystem functioning: Current understanding, pitfalls and future research needs. New Phytologist.

Freschet, G. T., Violle, C., Bourget, M. Y., Scherer-Lorenzen, M., \& Fort, F. (2018). Allocation, morphology, physiology, architecture: The multiple facets of plant above- and below-ground responses to resource stress. New Phytologist, 219(4), 1338-1352. https://doi.org/10.1111/nph.15225

Garnier, E., Laurent, G., Bellmann, A., Debain, S., Berthelier, P., Ducout, B., Roumet, C., \& Navas, M.L. (2001). Consistency of species ranking based on functional leaf traits. New Phytologist, 152(1), 69-83. https://doi.org/10.1046/j.0028-646x.2001.00239.x

Girardin, C., \& Mariotti, A. (1991). Analyse Isotopique Du 13C En Abondance Naturelle Dans Le Carbone Organique: Un Système Automatique Avec Robot Préparateur. Cahiers ORSTOM Série Pédologie, 26(4), 371-380.

Graefe, S., Hertel, D., \& Leuschner, C. (2008). Fine root dynamics along a 2,000-m elevation transect in South Ecuadorian mountain rainforests. Plant and Soil, 313(1-2), 155-166. https://doi.org/10.1007/s11104-008-9688-z

Guillot, S., Ménot, R.-P., \& Lardeaux, J.-M. (1992). Tectonique intra-océanique distensive dans l'ophiolite paléozoïque de Chamrousse (Alpes occidentales). Bulletin de La Société Géologique de France, 163(3), 229-240.

He, X., Hou, E., Liu, Y., \& Wen, D. (2016). Altitudinal patterns and controls of plant and soil nutrient concentrations and stoichiometry in subtropical China. Scientific Reports, 6(1), 24261. https://doi.org/10.1038/srep24261

Hendriks, M., Visser, E. J. W., Visschers, I. G. S., Aarts, B. H. J., de Caluwe, H., Smit-Tiekstra, A. E., van der Putten, W. H., de Kroon, H., \& Mommer, L. (2015). Root responses of grassland species to spatial heterogeneity of plant-soil feedback. Functional Ecology, 29(2), 177-186. https://doi.org/10.1111/1365-2435.12367

Hill, J. O., Simpson, R. J., Moore, A. D., \& Chapman, D. F. (2006). Morphology and response of roots of pasture species to phosphorus and nitrogen nutrition. Plant and Soil, 286(1-2), 7-19. https://doi.org/10.1007/s11104-006-0014-3

Hoch, G., \& Körner, C. (2012). Global patterns of mobile carbon stores in trees at the high-elevation tree line: A global analyses of $\mathrm{C}$ reserves in tree line trees. Global Ecology and Biogeography, 21(8), 861-871. https://doi.org/10.1111/j.1466-8238.2011.00731.x

Hodge, A. (2004). The plastic plant: Root responses to heterogeneous supplies of nutrients. New Phytologist, 162(1), 9-24. https://doi.org/10.1111/j.1469-8137.2004.01015.x

This article is protected by copyright. All rights reserved 
Holdaway, R. J., Richardson, S. J., Dickie, I. A., Peltzer, D. A., \& Coomes, D. A. (2011). Species- and community-level patterns in fine root traits along a 120 000-year soil chronosequence in temperate rain forest: Root trait shifts along soil chronosequence. Journal of Ecology, 99(4), 954963. https://doi.org/10.1111/j.1365-2745.2011.01821.x

Holtmeier, F.-K., \& Broll, G. (2005). Sensitivity and response of northern hemisphere altitudinal and polar treelines to environmental change at landscape and local scales: Treeline and environmental change. Global Ecology and Biogeography, 14(5), 395-410. https://doi.org/10.1111/j.1466822X.2005.00168.x

Hutchings, M. J., John, E. A., \& Wijesinghe, D. K. (2003). Toward understanding the consequences of soil heterogeneity for plant populations and communities. Ecology, 84(9), 2322-2334. https://doi.org/10.1890/02-0290

Jackson, R. B., Manwaring, J. H., \& Caldwell, M. M. (1990). Rapid physiological adjustment of roots to localized soil enrichment. Nature, 344, 58-59.

Jones, P. D., \& Briffa, K. R. (1995). Growing season temperatures over the former Soviet Union. International Journal of Climatology, 15(9), 943-959. https://doi.org/10.1002/joc.3370150902

Kembel, S. W., \& Cahill Jr., J. F. (2005). Plant Phenotypic Plasticity Belowground: A Phylogenetic Perspective on Root Foraging Trade- Offs. The American Naturalist, 166(2), 216-230. https://doi.org/10.1086/431287

Kichenin, E., Wardle, D. A., Peltzer, D. A., Morse, C. W., \& Freschet, G. T. (2013). Contrasting effects of plant inter- and intraspecific variation on community-level trait measures along an environmental gradient. Functional Ecology, 27(5), 1254-1261. https://doi.org/10.1111/13652435.12116

Kong, D., Ma, C., Zhang, Q., Li, L., Chen, X., Zeng, H., \& Guo, D. (2014). Leading dimensions in absorptive root trait variation across 96 subtropical forest species. New Phytologist, 203(3), 863872. https://doi.org/10.1111/nph.12842

Kong, D., Wang, J., Wu, H., Valverde-Barrantes, O. J., Wang, R., Zeng, H., Kardol, P., Zhang, H., \& Feng, Y. (2019). Nonlinearity of root trait relationships and the root economics spectrum. Nature Communications, 10(1), 2203. https://doi.org/10.1038/s41467-019-10245-6

Körner, C. (1998). A re-assessment of high elevation treeline positions and their explanation. Oecologia, 115(4), 445-459. https://doi.org/10.1007/s004420050540

Körner, C. (1999). Alpine plant life: Functional plant ecology of high mountain ecosystems. Springer.

Kotilínek, M., Hiiesalu, I., Košnar, J., Šmilauerová, M., Šmilauer, P., Altman, J., Dvorský, M., Kopecký, M., \& Doležal, J. (2017). Fungal root symbionts of high-altitude vascular plants in the Himalayas. Scientific Reports, 7(1), 6562. https://doi.org/10.1038/s41598-017-06938-x

This article is protected by copyright. All rights reserved 
Kramer-Walter, K. R., Bellingham, P. J., Millar, T. R., Smissen, R. D., Richardson, S. J., \& Laughlin, D. C. (2016). Root traits are multidimensional: Specific root length is independent from root tissue density and the plant economic spectrum. Journal of Ecology, 104(5), 1299-1310. https://doi.org/10.1111/1365-2745.12562

Kumordzi, B. B., Aubin, I., Cardou, F., Shipley, B., Violle, C., Johnstone, J., Anand, M., Arsenault, A., Bell, F. W., Bergeron, Y., Boulangeat, I., Brousseau, M., De Grandpré, L., Delagrange, S., Fenton, N. J., Gravel, D., Macdonald, S. E., Hamel, B., Higelin, M., ... Munson, A. D. (2019). Geographic scale and disturbance influence intraspecific trait variability in leaves and roots of North American understorey plants. Functional Ecology, 33(9), 1771-1784. https://doi.org/10.1111/1365-2435.13402

Lauber, K., Wagner, G., \& Gygax, A. (2018). Flora Helvetica-Flore Illustrée de Suisse (5th ed.). Haupt Verlag.

Loomis, P. F., Ruess, R. W., Sveinbjörnsson, B., \& Kielland, K. (2006). Nitrogen cycling at treeline: Latitudinal and elevational patterns across a boreal landscape. Ecoscience, 13(4), 544-556. https://doi.org/10.2980/1195-6860(2006)13[544:NCATLA]2.0.CO;2

Ma, Z., Guo, D., Xu, X., Lu, M., Bardgett, R. D., Eissenstat, D. M., McCormack, M. L., \& Hedin, L. O. (2018). Evolutionary history resolves global organization of root functional traits. Nature, 555(7694), 94-97. https://doi.org/10.1038/nature25783

Mayor, J. R., Sanders, N. J., Classen, A. T., Bardgett, R. D., Clément, J.-C., Fajardo, A., Lavorel, S., Sundqvist, M. K., Bahn, M., Chisholm, C., Cieraad, E., Gedalof, Z., Grigulis, K., Kudo, G., Oberski, D. L., \& Wardle, D. A. (2017). Elevation alters ecosystem properties across temperate treelines globally. Nature, 542(7639), 91-95. https://doi.org/10.1038/nature21027

McCormack, M. L., Adams, T. S., Smithwick, E. A. H., \& Eissenstat, D. M. (2012). Predicting fine root lifespan from plant functional traits in temperate trees. New Phytologist, 195(4), 823-831. https://doi.org/10.1111/j.1469-8137.2012.04198.x

McCormack, M. L., \& Iversen, C. M. (2019). Physical and Functional Constraints on Viable Belowground Acquisition Strategies. Frontiers in Plant Science, 10, 1215. https://doi.org/10.3389/fpls.2019.01215

Ménot, R.-P. (1988). The geology of the Belledonne massif: An overview (external crystalline massifs of the Western Alps). https://doi.org/10.5169/SEALS-52088

Messier, J., McGill, B. J., \& Lechowicz, M. J. (2010). How do traits vary across ecological scales? A case for trait-based ecology: How do traits vary across ecological scales? Ecology Letters, 13(7), 838848. https://doi.org/10.1111/j.1461-0248.2010.01476.x

This article is protected by copyright. All rights reserved 
Midolo, G., De Frenne, P., Hölzel, N., \& Wellstein, C. (2019). Global patterns of intraspecific leaf trait responses to elevation. Global Change Biology, gcb.14646. https://doi.org/10.1111/gcb.14646

Moore, A. (1986). Temperature and moisture dependence of decomposition rates of hardwood and coniferous leaf litter. Soil Biology and Biochemistry, 18(4), 427-435. https://doi.org/10.1016/0038-0717(86)90049-0

Ninyerola, M., Pons, X., \& Roure, J. M. (2000). A methodological approach of climatological modelling of air temperature and precipitation through GIS techniques. Int. J. Climatol., 21.

Niu, K., Zhang, S., \& Lechowicz, M. J. (2020). Harsh environmental regimes increase the functional significance of intraspecific variation in plant communities. Functional Ecology, 34(8), 16661677. https://doi.org/10.1111/1365-2435.13582

Olsen, S. R., Cole, C. V., Watanabe, F. S., \& Dean, L. A. (1954). Estimation of available phosphorus in soils by extraction with sodium bicarbonate. U.S. Department of Agriculture.

Ostonen, I., Lohmus, K., Helmisaari, H.-S., Truu, J., \& Meel, S. (2007). Fine root morphological adaptations in Scots pine, Norway spruce and silver birch along a latitudinal gradient in boreal forests. Tree Physiology, 27(11), 1627-1634. https://doi.org/10.1093/treephys/27.11.1627

Ostonen, I., Püttsepp, Ü., Biel, C., Alberton, O., Bakker, M. R., Lõhmus, K., Majdi, H., Metcalfe, D., Olsthoorn, A. F. M., Pronk, A., Vanguelova, E., Weih, M., \& Brunner, I. (2007). Specific root length as an indicator of environmental change. Plant Biosystems - An International Journal Dealing with All Aspects of Plant Biology, 141(3), 426-442. https://doi.org/10.1080/11263500701626069

Ostonen, I., Helmisaari, H.-S., Borken, W., Tedersoo, L., Kukumägi, M., Bahram, M., Lindroos, A.-J., Nöjd, P., Uri, V., Merilä, P., Asi, E., \& Lõhmus, K. (2011). Fine root foraging strategies in Norway spruce forests across a European climate gradient. Global Change Biology, 17(12), 3620-3632. https://doi.org/10.1111/j.1365-2486.2011.02501.x

Pansu, M., \& Gautheyrou, J. (2006). Handbook of Soil Analysis: Mineralogical, Organic and Inorganic Methods. Springer.

Peterson, CarolA., Murrmann, M., \& Steudle, E. (1993). Location of the major barriers to water and ion movement in young roots of Zea mays L. Planta, 190(1). https://doi.org/10.1007/BF00195684

Piedallu, C., Chéret, V., Denux, J. P., Perez, V., Azcona, J. S., Seynave, I., \& Gégout, J. C. (2019). Soil and climate differently impact NDVI patterns according to the season and the stand type. Science of The Total Environment, 651, 2874-2885. https://doi.org/10.1016/j.scitotenv.2018.10.052

Piedallu, Christian, Gégout, J.-C., Perez, V., \& Lebourgeois, F. (2013). Soil water balance performs better than climatic water variables in tree species distribution modelling: Soil water balance improves

This article is protected by copyright. All rights reserved 
tree species distribution models. Global Ecology and Biogeography, 22(4), 470-482. https://doi.org/10.1111/geb.12012

R Core Team. (2019). R: A Language and Environment for Statistical Computing. R Foundation for Statistical Computing. https://www.R-project.org/

Read, D. J., Leake, J. R., \& Perez-Moreno, J. (2004). Mycorrhizal fungi as drivers of ecosystem processes in heathland and boreal forest biomes. Canadian Journal of Botany, 82(8), 1243-1263. https://doi.org/10.1139/b04-123

Read, Q. D., Henning, J. A., \& Sanders, N. J. (2017). Intraspecific variation in traits reduces ability of trait-based models to predict community structure. Journal of Vegetation Science, 28(5), 10701081. https://doi.org/10.1111/jvs. 12555

Rose, L. (2017). Pitfalls in Root Trait Calculations: How Ignoring Diameter Heterogeneity Can Lead to Overestimation of Functional Traits. Frontiers in Plant Science, 8, 898. https://doi.org/10.3389/fpls.2017.00898

Roybal, C. M., \& Butterfield, B. J. (2019). Species-specific trait-environment relationships among populations of widespread grass species. Oecologia, 189(4), 1017-1026. https://doi.org/10.1007/s00442-019-04372-6

Ryser, P. (1996). The Importance of Tissue Density for Growth and Life Span of Leaves and Roots: A Comparison of Five Ecologically Contrasting Grasses. Functional Ecology, 10(6), 717. https://doi.org/10.2307/2390506

Ryser, P., \& Eek, L. (2000). Consequences of phenotypic plasticity vs. Interspecific differences in leaf and root traits for acquisition of aboveground and belowground resources. American Journal of Botany, 87(3), 402-411. https://doi.org/10.2307/2656636

See, C. R., McCormack, L. M., Hobbie, S. E., Flores- Moreno, H., Silver, W. L., \& Kennedy, P. G. (2019). Global patterns in fine root decomposition: Climate, chemistry, mycorrhizal association and woodiness. Ecology Letters, 22(6), 946-953. https://doi.org/10.1111/ele.13248

Siefert, A., Violle, C., Chalmandrier, L., Albert, C. H., Taudiere, A., Fajardo, A., Aarssen, L. W., Baraloto, C., Carlucci, M. B., Cianciaruso, M. V., de L. Dantas, V., de Bello, F., Duarte, L. D. S., Fonseca, C. R., Freschet, G. T., Gaucherand, S., Gross, N., Hikosaka, K., Jackson, B., ... Wardle, D. A. (2015). A global meta-analysis of the relative extent of intraspecific trait variation in plant communities. Ecology Letters, 18(12), 1406-1419. https://doi.org/10.1111/ele.12508

Sultan, S. E. (2000). Phenotypic plasticity for plant development, function and life history. Trends in Plant Science, 5(12), 537-542. https://doi.org/10.1016/S1360-1385(00)01797-0

Sundqvist, M. K., Sanders, N. J., \& Wardle, D. A. (2013). Community and Ecosystem Responses to Elevational Gradients: Processes, Mechanisms, and Insights for Global Change. Annual Review of

This article is protected by copyright. All rights reserved 
Ecology, Evolution, and Systematics, 44(1), 261-280. https://doi.org/10.1146/annurev-ecolsys110512-135750

Sveinbjornsson, B., Davis, J., Abadie, W., \& Butler, A. (1995). Soil Carbon and Nitrogen Mineralization at Different Elevations in the Chugach Mountains of South-Central Alaska, U.S.A. Arctic and Alpine Research, 27(1), 29. https://doi.org/10.2307/1552065

Valladares, F., Gianoli, E., \& Gómez, J. M. (2007). Ecological limits to plant phenotypic plasticity. New Phytologist, 176(4), 749-763. https://doi.org/10.1111/j.1469-8137.2007.02275.x

Valverde-Barrantes, O. J., Smemo, K. A., Feinstein, L. M., Kershner, M. W., \& Blackwood, C. B. (2013). The distribution of below-ground traits is explained by intrinsic species differences and intraspecific plasticity in response to root neighbours. Journal of Ecology, 101(4), 933-942. https://doi.org/10.1111/1365-2745.12087

Violle, C., Enquist, B. J., McGill, B. J., Jiang, L., Albert, C. H., Hulshof, C., Jung, V., \& Messier, J. (2012). The return of the variance: Intraspecific variability in community ecology. Trends in Ecology \& Evolution, 27(4), 244-252. https://doi.org/10.1016/j.tree.2011.11.014

Vries, F. T., Williams, A., Stringer, F., Willcocks, R., McEwing, R., Langridge, H., \& Straathof, A. L. (2019). Changes in root- exudate- induced respiration reveal a novel mechanism through which drought affects ecosystem carbon cycling. New Phytologist, 224(1), 132-145. https://doi.org/10.1111/nph.16001

Weemstra, M., Sterck, F. J., Visser, E. J. W., Kuyper, T. W., Goudzwaard, L., \& Mommer, L. (2017). Fine-root trait plasticity of beech (Fagus sylvatica) and spruce (Picea abies) forests on two contrasting soils. Plant and Soil, 415(1-2), 175-188. https://doi.org/10.1007/s11104-016-3148-y

Weemstra, M., 2020, "Species-level root trait data (ECOPICS)", https://doi.org/10.15454/J1QDPM, Portail Data INRAE.

Westoby, M., Falster, D. S., Moles, A. T., Vesk, P. A., \& Wright, I. J. (2002). Plant Ecological Strategies: Some Leading Dimensions of Variation between Species. Annual Review of Ecology and Systematics, 3, 125-159.

Zadworny, M., McCormack, M. L., Mucha, J., Reich, P. B., \& Oleksyn, J. (2016). Scots pine fine roots adjust along a 2000-km latitudinal climatic gradient. New Phytologist, 212(2), 389-399. https://doi.org/10.1111/nph.14048

Zhao, N., Yu, G., He, N., Xia, F., Wang, Q., Wang, R., Xu, Z., \& Jia, Y. (2016). Invariant allometric scaling of nitrogen and phosphorus in leaves, stems, and fine roots of woody plants along an altitudinal gradient. Journal of Plant Research, 129(4), 647-657. https://doi.org/10.1007/s10265016-0805-4

This article is protected by copyright. All rights reserved 
Zhou, M., Wang, J., Bai, W., Zhang, Y., \& Zhang, W. (2019). The response of root traits to precipitation change of herbaceous species in temperate steppes. Functional Ecology, 33(10), 2030-2041. https://doi.org/10.1111/1365-2435.13420

\section{Figure captions}

Figure 1. Percentage of total trait variance explained by different biologically hierarchical levels, i.e., between growth forms (grasses, forbs, shrubs and trees), between species, intraspecific trait variation between elevations $\left(\mathrm{ITV}_{\text {between }}\right)$ and within elevations $\left(\mathrm{ITV}_{\text {within }}\right)$. SRL, specific root length; Diam., root mean diameter; RTD, root tissue density; BD, root branching density

Figure 2. Observed variation in root traits along an elevation gradient within species. Each data point represents a trait value for an individual plant. Regression lines indicate significant relationships between root traits and elevation within a species. Model statistics are presented in Supplementary Table S2. Colours refer to growth forms (light-green, grass; purple, forbs; dark-green, shrubs; dark-blue, trees). Light-grey vertical bands indicate the altitude of the treeline. Species abbreviations are explained in Table 1. Note the log-scale of the y-axis.

Figure 3. Significant relationships $(\mathrm{P}<0.05)$ between traits and elevation and (single) environmental variables within species and across all plants. Lines qualitatively illustrate the shape (linear or quadratic) and direction (positive or negative) of these relationships. Thick lines indicate the best model explaining trait variation per species (i.e., based on lowest AIC); models were considered equally good if the difference in their AIC $(\triangle \mathrm{AIC})<2$, thin lines indicate models for which $\triangle \mathrm{AIC}>2$. Empty cells imply that no significant trait responses were found. Model statistics on trait-elevation and trait-environment relationships within species and across all plants are presented in Supplementary Tables S2-S5. MAT, mean annual temperature; MAP, mean annual precipitation; CEC, soil cation exchange capacity; sand, soil sand content; $\mathrm{pH}$, soil $\mathrm{pH}$; total $\mathrm{N}$, soil total nitrogen content; Cover, percentage of the ground area covered by vegetation. Species abbreviations are explained in Table 1.

Figure 4. Variation in root traits in relation to the main relevant environmental variable identified within species (coloured lines referring to different species) and across all plants (black line); only significant relationships are shown. a) Specific root length with mean annual precipitation; b) root diameter with mean annual precipitation; c) root tissue density with vegetation ground cover; d) branching density with 


\section{Table and Figures}

Table 1. Species information. Mycorrhizal association (AM, arbuscular mycorrhizal; EcM, ectomycorrhizal; ErM, ericoid mycorrhizal; NM, nonmycorrhizal); Elevation, elevation (m a.s.1.) at which a species occurs in the French Alps (www.FloreAlpes.com 2019); Sampling range (m a.s.1.), range of elevations at which species were sampled; $n$ per trait, number of observations per species per trait.

\begin{tabular}{|c|c|c|c|c|c|c|c|}
\hline Species & Species abbreviation & Family & Growth form & Mycorrhizal association & Elevation & Sampling range & n per trait \\
\hline Anthoxanthum odoratum & AODOR & Poaceae & Grass & $\mathrm{AM}^{1}$ & $0-3100$ & $1400-2000$ & 36 \\
\hline Carex sempervirens & CSEMP & Cyperaceae & Grass & $\mathrm{AM}+\mathrm{NM}^{1,2}$ & $1500-2400$ & $1800-2400$ & 35 \\
\hline Deschampsia flexиosa & DFLEX & Poaceae & Grass & $\mathrm{AM}^{1}$ & $300-2800$ & $1400-2400$ & 54 \\
\hline Nardus stricta & NSTRI & Poaceae & Grass & $\mathrm{AM}^{1}$ & $400-3000$ & $1700-2400$ & 40 \\
\hline Gentiana acaulis & GACAU & Gentianaceae & Forb & $\mathrm{AM}^{2}$ & $1400-3000$ & $1700-2400$ & 39 \\
\hline Homogyne alpine & HALPI & Asteraceae & Forb & $\mathrm{AM}+\mathrm{EcM}^{2}$ & $0-3000$ & $1700-2400$ & 30 \\
\hline Peucedanum ostruthium & POSTR & Apiaceae & Forb & $\mathrm{AM}^{2}$ & $1000-2900$ & $1500-2400$ & 40 \\
\hline Juniperus communis & JCOMM & Cupressaceae & Shrub & $\mathrm{AM}^{1}$ & $0-2500$ & $1700-2400$ & 40 \\
\hline Vaccinium myrtillus & VMYRT & Ericaceae & Shrub & $\operatorname{ErM}^{1}$ & $0-2800$ & $1400-2400$ & 54 \\
\hline Picea abies & PABIE & Pinaceae & Tree & $\mathrm{EcM}^{1}$ & $0-2200$ & $1400-2000$ & 35 \\
\hline Sorbus aucuparia & SAUCU & Rosaceae & Tree & $\mathrm{AM}^{1}$ & $0-2000$ & $1400-1900$ & 31 \\
\hline
\end{tabular}




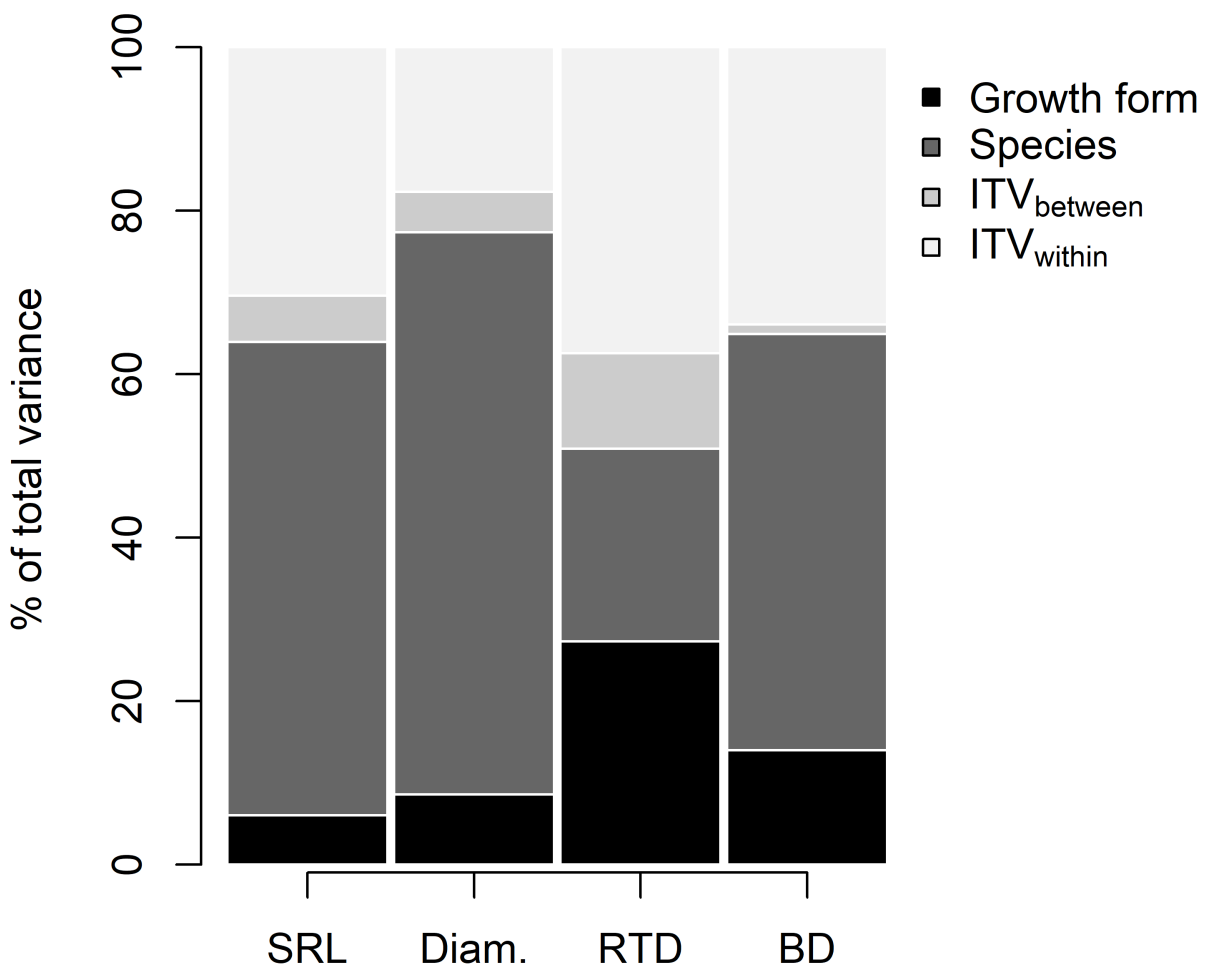

fec_13723_f1.tiff 

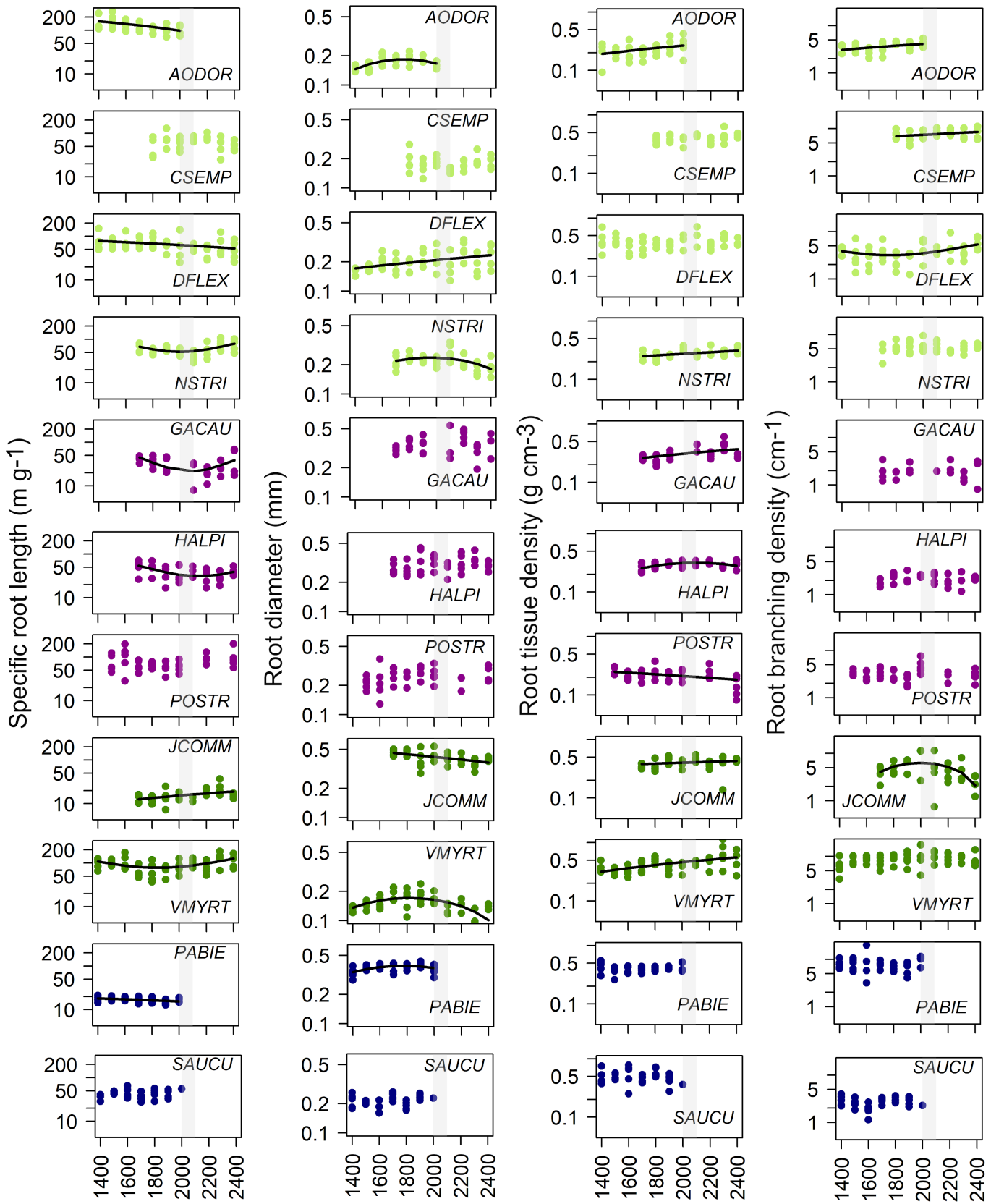

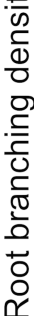
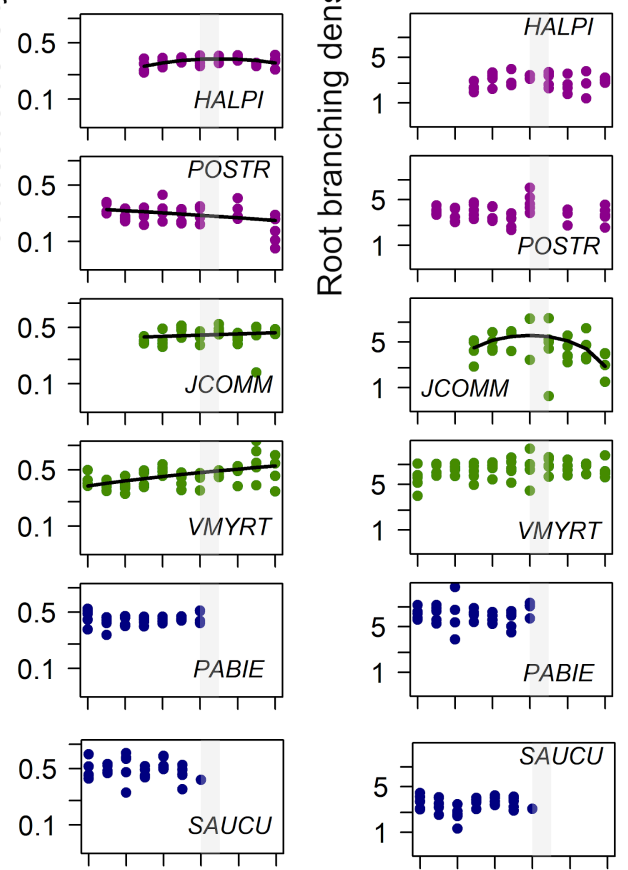

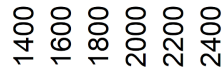
엄 은 융 융워

Elevation (m a.s.I.) 
a) Specific root length

\begin{tabular}{|c|c|c|c|c|c|c|c|c|}
\hline & Elev. & MAT & MAP & CEC & Sand & pH & $\mathrm{N}$ & Cover \\
\hline AODOR & & & & & & & & \\
\hline CSEMP & & & & & & & & \\
\hline DFLEX & & & & & & & & \\
\hline NSTRI & & & & & & & & \\
\hline GACAU & & & & & & & & \\
\hline HALPI & & & & & & & & 1 \\
\hline POSTR & & & & & & & & \\
\hline JCOMM & & & & & $\bigcap$ & & & \\
\hline VMYRT & & & & & & & & \\
\hline PABIE & & & & & & & & \\
\hline SAUCU & & & & & & & & \\
\hline All plants & 11 & & & & & & & \\
\hline
\end{tabular}

c) Root tissue density

\begin{tabular}{|c|c|c|c|c|c|c|c|c|}
\hline & Elev. & MAT & MAP & CEC & Sand & $\mathrm{pH}$ & $\mathrm{N}$ & Cover \\
\hline AODOR & & & & & & & & \\
\hline CSEMP & & & & & & & & \\
\hline DFLEX & & & & & & & & \\
\hline NSTRI & & & & & & & & \\
\hline GACAU & & & & & & & & \\
\hline HALPI & & 1 & & & & & & \\
\hline POSTR & & & & $r$ & & & & \\
\hline JCOMM & & & & & & & & \\
\hline VMYRT & & & & & & & & \\
\hline PABIE & & & & & & & & \\
\hline SAUCU & & & & & & & & \\
\hline All plants & & & & & & & & \\
\hline
\end{tabular}

b) Root diameter

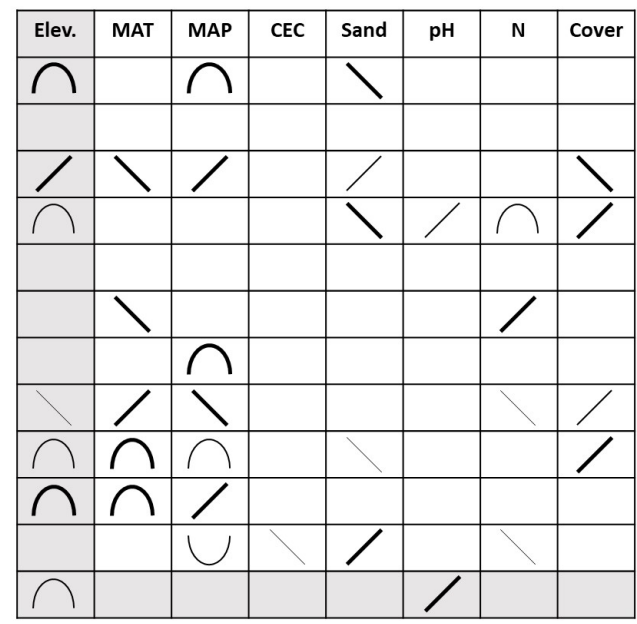

d) Root branching density

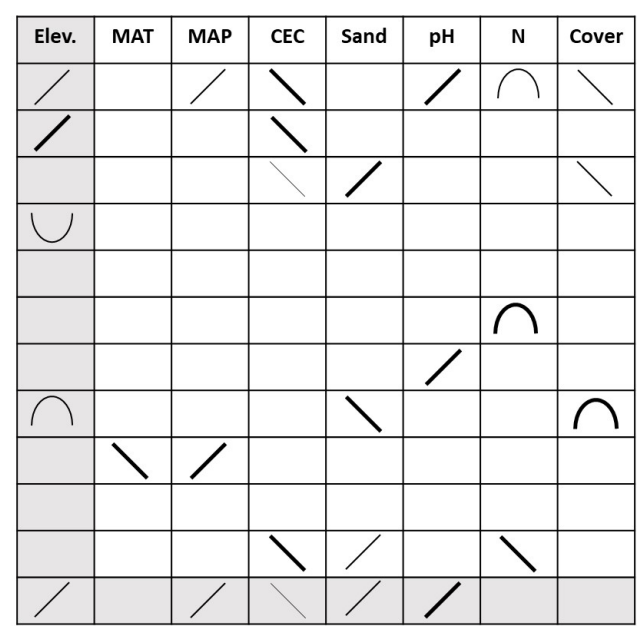

fec_13723_f3.jpg 


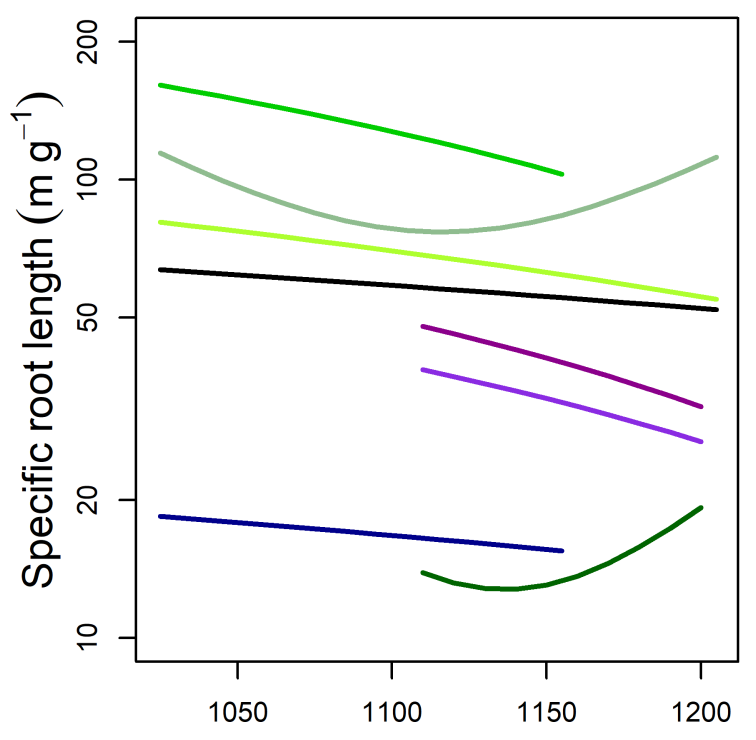

Mean annual precipitation ( $\mathrm{mm}$ )

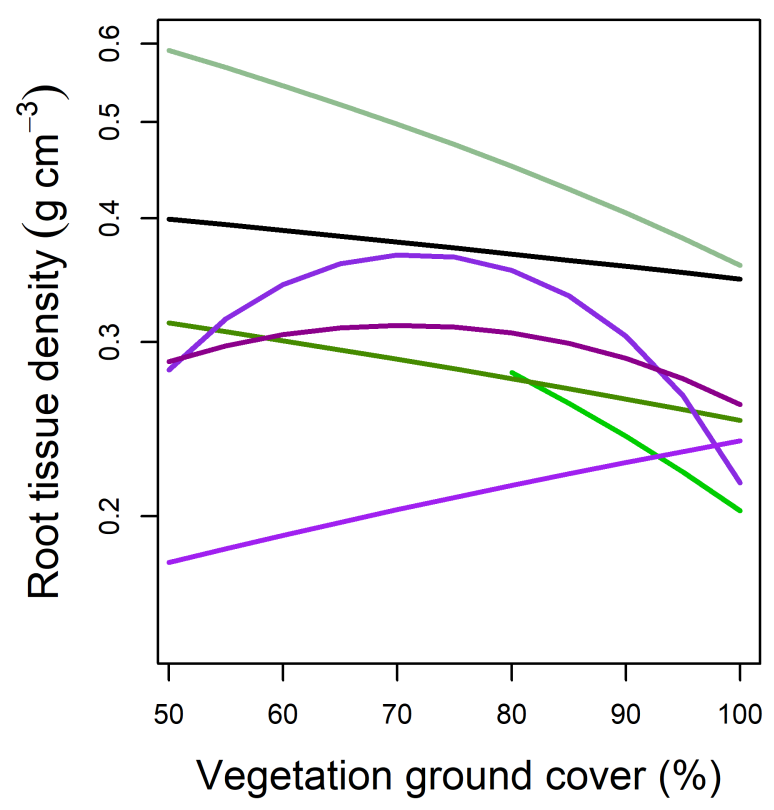

AODOR

CSEMP DFLEX NSTRI

GACAU

HALPI

POSTR

JCOMM

VMYRT

PABIE

SAUCU

All plants

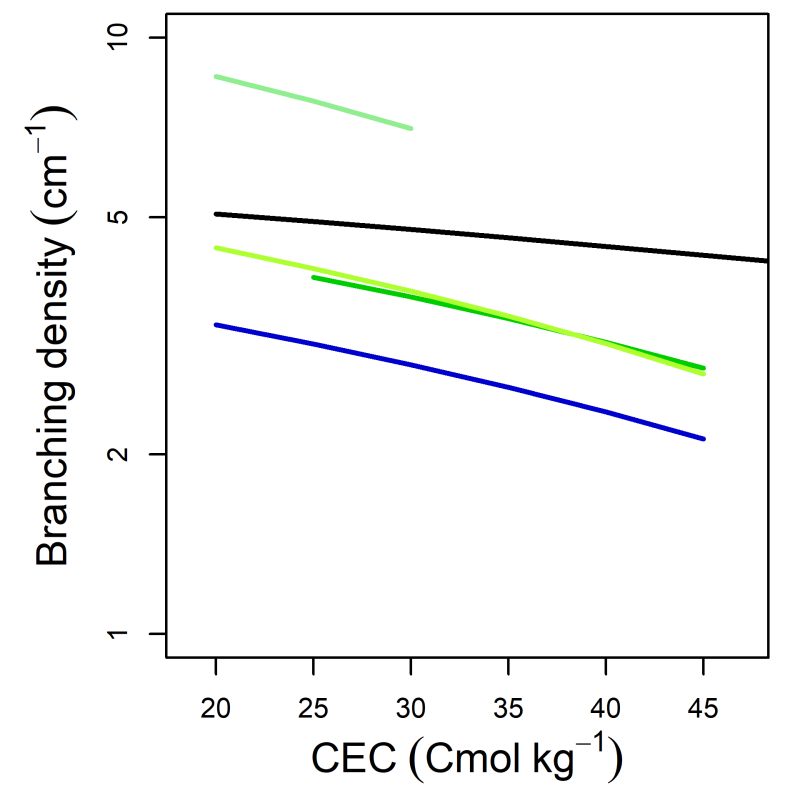

